HABITAT, 32 (1), 2021, 1-10

DOI: 10.21776/ub.habitat.2021.032.1.1

\title{
Empowering Indigenous Farmers with Fish Farming on South Sumatra Peatlands
}

\author{
Elisa Wildayana*, M. Edi Armanto \\ Faculty of Agriculture, Sriwijaya University, Palembang-Prabumulih St KM 32, Indralaya Campus \\ (30662), South Sumatra Indonesia.
}

Received: 24 July 2017; Revised: 10 October 2020; Accepted: 23 October 2020

\begin{abstract}
Forest and land fire is mentioned as a main problem of peatlands occurring every year and has provided huge losses for all parties. The research aimed how to empower indigenous farmers with fish farming on South Sumatra peatlands. This research was conducted on peatlands in Ogan Komering Ilir (OKI) District. The sampling method was using cluster technique, questionnaire and through Focus Discussion Group (FDG). All collected data were analyzed with the SPSS version 21 program and the comparisons or analyzes the relationship between the variables were also analyzed. The research results concluded that the prospect of fish farming on peatlands is very prospecful. Empowering indigenous farmers can be done through local fish farming (e.g. fishes of gabus; tebakang; sepat siam; betok; gurami and toman), and introduced fish farming (i.e. fishes of patin siam; catfish, and nila). Fish farming technology for empowering farmers can be focused on drainage and irrigation systems to maintain groundwater levels; and applying soil ameliorant (e.g. dolomite for fish ponds, lime, manure, urea and NPK fertilizer).
\end{abstract}

Keywords: empowering; indigenous: farmers; farming; peatlands

\section{How to cite:}

Wildayana, E., \& Armanto, M. E. (2021). Empowering Indigenous Farmers With Fish Farming On South Sumatra Peatlands. HABITAT, 32(1), 1-10. https://doi.org/10.21776/ub.habitat.2021.032.1.1

\section{Introduction}

Peatlands belong to wetlands needing special attention. Indonesia has the fourth largest peatland in the world with an area of about 20.60 million ha and this area covers around $40-50 \%$ of the world's tropical peatlands or around $10.80 \%$ of Indonesia territorial area and are mainly spread in Kalimantan, Sumatra and Papua. From this area about 7.20 million ha or $35 \%$ of them are found in Sumatra, which is generally distributed along the eastern coast of Sumatra, namely in Riau, South Sumatra, Jambi, North Sumatra, and Lampung. In South Sumatra province about 1.40 million ha of peatlands are global concern because most of these peatlands are damaged by forest and land fires (BPS South Sumatra, 2016). Burned peatlands occur almost every year, and then a natural vegetation succession is made up of ferns and swamp grasses. The largest peatland area is found in Ogan Komering Ilir (OKI) and Banyuasin districts, covering an area of around

${ }^{*}$ Corressponding author.

E-mail: ewildayana@unsri.ac.id

Telp: +628127338950
769 thousand ha. The area of swamp including peatlands and lake reaches about $75 \%$ of the total area of OKI district (Armanto et al., 2013).

Peatlands are part of natural resources having many functions, among others as a means of conserving water resources, reducing floods, preventing sea water intrusion, biodiversity habitats and climate control (through the ability of peatlands to store carbon). Till now potential of peatlands is still not widely used especially for the fishery sector (Wildayana et al., 2016).

The main international issues of peatlands are climate change, peat fires and peatland conversion. The current issue of forest and peatland fires is increasing and certainly has an impact on the environment and socioeconomic conditions, among others creating smoke that provides high economic losses (Firmansyah et al., 2016; Adriani and Wildayana, 2015). The amount of carbon emissions that come out in the event of fire occurs can reach $13-40 \%$ of the total global carbon emissions production, making Indonesia as the largest polluters in the world (Haden et al., 2013; Hooijer et al., 2012; IPCC, 2014, Dikici and Yilmaz, 2006). Generally the development of freshwater fish farming is still 
dominated by the cultivation of ponds using water from the tides of the river (Ismawi et al., 2012; Lampela et al., 2014; Könönen et al., 2015). Thus it is often constrained by the arrival of acidic water with very low $\mathrm{pH}$ values (less than 4.20) to cause total fish death. The low $\mathrm{pH}$ factor is a major constraint for the development of fish farming (Oktavia et al., 2014; Sarno et al., 2017).

This research has a single objective, namely empowerment of fish farming by empowering through diversification of cultivated fish species. Strategies to overcome the low $\mathrm{pH}$ problem for fisheries can be done through a biological approach, namely the optimal use of local fish that have adapted to the environment. The types of local fish of the peatlands are dominated by the types of fishes that can breathe using oxygen from the air (air breathing), such as gabus (Channa striata), toman (Channa micropeltes), ikan betok (Anabas testudineus), tebakang/biawan (Helostoma temminckii), sepat siam (Trichogaster pectolaris), and gurame (Osphronemus gouramy). Another biological approach strategy is to introduce fish-resistant fish with acidic $\mathrm{pH}$ conditions, such as patin siam (Pangasianodon hypophthalmus), lele dumbo (Clarias gariepinus), dan ikan nila (Oreochromis niloticus) and others. In relation to the above issues, the research aimed how to empower indigneous farmers with fish farming on South Sumatra peatlands.

\section{Research Methods}

This research uses a combination approach between qualitative and quantitative methods. This research has been conducted on peatlands in Ogan Komering Ilir (OKI) District, South Sumatra using survey method to find data and information related to indigenous farmers with fish farming. Sampling using cluster technique is a technique of selecting samples using probability principles on the basis of groups of indigenous farmers who naturally gather together. Data collection was carried out by combining several methods, such as interview method with questionnaire and direct observation in the field. Interviews with respondents were structured with questionnaire and unstructured through Focus Discussion Group (FDG).

Two types of questionnaires used were open questionnaires and closed questionnaires. An open questionnaire gave freedom to respondents to answer questions; in the meantime, a closed questionnaire has provided a selection of answers to be chosen by respondents. Document study is done by conducting document analysis related to the research theme. All collected data were analyzed with the SPSS version 21 program and in the next stage comparisons or analyzes the relationship between the variables.

\section{Results and Discussions}

The results and discussion of this research emphasized on several important aspects related to fish farming, among others general condition of research location; main problem of peatlands at research location; empowering indigenous farmers by local fish farming; empowering indigenous farmers by introduced fish farming; and empowering indigneous farmers with technology approach.

\subsection{General Condition of Research Location}

The research location belongs to peatland physiographic type and is not affected by river tides and sea tides. It is located in Talang Sepucuk peatlands which is included to Peat Hydrological Unit of the Sibumbung Komering River and located in Sub-Districts of Pedamaran and East Pedamaran, Kayuagung, District of Ogan Komering Ilir, OKI (Figure 1). $\underline{\text { Research location }}$

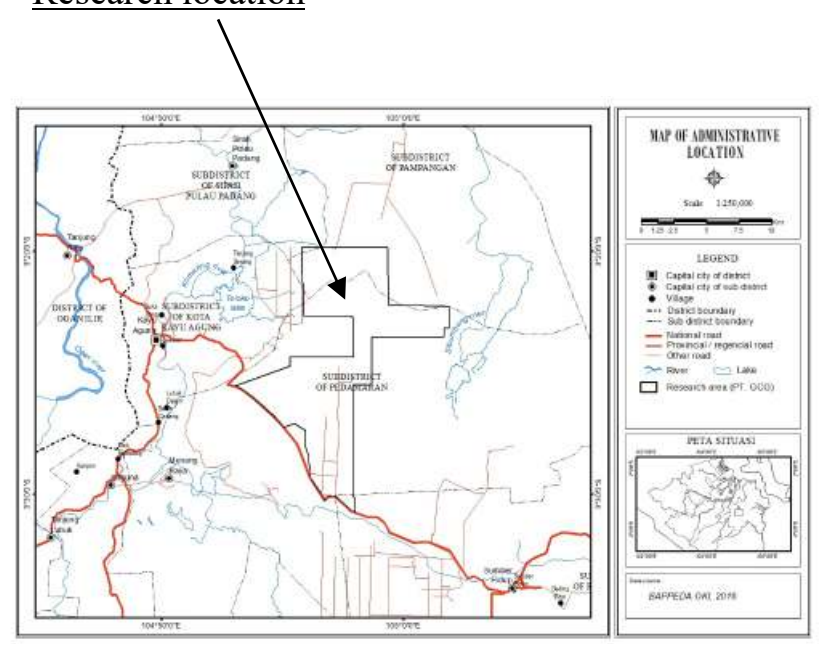

Figure 1. Research location of Talang Sepucuk, Kayu Agung, OKI

District of Ogan Komering Ilir (OKI) is sited in the South-East of South Sumatra, exactly between $104^{\circ} 20^{\prime}$ and $106^{\circ} 00^{\prime}$ East Longitude and $2^{\circ} 30^{\prime}$ to $4^{\circ} 15^{\prime}$ South Latitude, covering $19,023.47 \mathrm{~km}^{2}$. This area is flooded by many rivers and has coastal and marine areas. Thus, OKI district can be distinguished into lowland and terrain that show higher 
topography (upland). Approximately $75 \%$ of the total area of OKI district is classified as a swamp area and can be found in the eastern region such as Air Sugihan, Tulung Selapan, Cengal and Sungai Menang Subdistricts and around $25 \%$ belongs to upland area.

The peatlands in OKI district are mostly used by HTI producing paper and has been cultivated by three forest plant business permit holders, namely PT. SBA Wood Industries, PT. Bumi Andalas Permai dan PT. Bumi Mekar Hijau that plants Acacia crassicarpa. The decline of peatlands in OKI district was due to fires not only to provide harm to human life, but also to affect other living things. If fires continue to happen in the future, of course, the peatlands will be more lost, the ecosystem is more unbalanced then the earth will be more polluted. The sustainability of peatlands is increasingly questionable.

Many local communities make peatlands as their livelihood. Dependence on peatlands is evident with the ricefields, plantations and other economic resources belonging to the local people. The existence of peatlands is certainly a boon for themselves and if peatlands are decreasing, it will certainly be a serious problem for them if it is viewed from the socio-economic and cultural aspects. Drainage of peatlands by making canals is still done by the community. Peat drainage is done for making road infrastructure and its impact is that people are always flooded during the rainy season, as happened in Ulak Kedondong village, Cengal Subdistrict.

The government has issued a policy to defend the peatlands from degradation getting worse, i.e. by sparking a peat moratorium. This moratorium contains policies on the granting of new licenses for natural forests and peatlands in conservation forest, protection forest, production forest (limited production forest, fixed production forest, convertible forest products) and other uses for use in the plantation sector. This moratorium does not apply to the extension of forest utilization permits and/or the use of existing forest areas as long as the license in the business field is still in effect.

This moratorium is considered to be one of the positive efforts as a conservation of peatlands that has a great role to the world's wetland ecosystem. However, according to some environmental experts, the peat moratorium is considered to disrupt the business sector. With the moratorium, companies engaged in the field of peat cultivation will be disrupted, and cause the absorption of labor and the acquisition of foreign exchange will also be reduced.

Regardless of the moratorium-related debate, efforts to expand fire prevention are not only imposed on the parties involved in the use of peat resources alone, but the contribution of all elements of society is also needed, since peat is a natural resource that deserves our sustainability. Providing alternative solutions in addition to peat-based agriculture in peatlands for farmers is urgently needed so that in the future the farmers are more aware of the advantages and disadvantages of peatlands. Education also needs to be done to investors and companies conducting cultivation in peatlands; the need for awareness of peat maintenance and the preparation of land in a healthy way will be able to maintain the sustainability of peatland that is now beginning to decrease.

Another effort we can take to maintain the sustainability of peat is to stop destruction by protecting forests and peatlands (including taking rapid measures to prevent fires). An agreement between traders (buyer companies) to collaborate and take joint action to ensure if there are companies that still create conditions of fire and smoke by draining peatlands and destroying forests to be removed from the market.

Efforts to repair forest destruction, such as forest loss due to rehabilitation fires, have entered into efforts to safeguard and restore forest conditions to function properly. Rehabilitation efforts should prioritize vulnerable peatland areas that have been exposed to forest fires. Finally, by providing solutions to communities to develop livelihood resources that support forest conservation and restoration including improving crop yields in existing plantation areas and supporting the development of cooperatives can also be an effective step in safeguarding the economy and the environment.

This moratorium is considered to be one of the positive efforts as a conservation of Indonesia's peat that has a great role to the world's wetland ecosystem. However, according to some environmental experts, the peat moratorium is considered to disrupt the business sector. With the moratorium, companies 
engaged in the field of peat cultivation will be disrupted, and cause the absorption of labor and the acquisition of foreign exchange will also be reduced.

\subsection{Main Problems of Peatlands}

The main factors of the fire can be classified into two namely the trigger of fire and supporting conditions. Fire triggers are factors that directly affect the occurrence of ignition. These fire triggers can be caused by intentional or unintentional human activity or negligence. There is no specific empowerment that is directly related to the the fire triggers. In addition, fire triggers can also be caused by natural factors such as lightning and friction between dry branches. Drought is also one of the natural factors that can trigger the occurrence of forest and land fires. South Sumatra has become a potential or vulnerable area for large-scale fires caused by human activities, namely:

\section{a. Land Preparation}

Land preparation is often done by the community or company. Land preparation by burning is still often done because it tends to be more practical, easy to do with simple equipment, and does not cost a lot of expensive and labor that used not much. Communities living around the peat swamp forests have been used and hereditary to use fire to prepare peatlands as plantation and agricultural land. Land preparation in this way is known as the sonor system. Inadequate fire control will result in uncontrolled and widespread burning as the peatlands become very dry during the dry season.

\section{b. Land Conflict}

Land conflicts are the main motive of occurrence for the burning of forests and land. Fire is often used by local people as a means to plunder no man's land. Land conflicts often occur between local communities and HTI companies whose land is close together. An examples of cases in Ulak Kedondong Village, Cengal OKI, since 2009 local people have no longer done their sonor systems (traditional rice cultivation systems in swamp areas during drought) because their land was previously used for sonor systems becoming a concession of PT. Bumi Mekar Hijau (BMH), which in 2015 has been burned. Another problem is the status of peatlands that are still in the area of production forest (HP) area of around 300 ha which the government has declared as HP area. According to the community, the land has been managed for generations since the early 1960s ago before the government set the land to become an area of HP. The land in our village is still also in production forest (HP). The status of the village lands that enter the production forest has caused the community to be less concerned with the environment, especially peatland. If this status is removed and given to the community, it is likely that they will be more concerned about peatlands.

\section{c. Human Ignorance}

Human ignorance in using unwise fire causes often the fire source. Throwing cigarette butts in the peatlands or not comprehensive fire extinguishing cause the fire increasingly widespread because forest and land fires can no longer be controlled. In addition to supporting conditions, the causes of forest and land fires are also caused by several supporting factors such as climatic conditions, physical land conditions, and socio-economic culture of the surrounding community. Dry and hot climatic conditions trigger fires. Fire occurs during the dry season where rainfall is very low and the intensity of solar heat is high. Fire will be higher if it is found the symptoms of El Nino. Fire will decrease if it has entered the rainy season where the intensity of heat will decrease. The physical condition of degraded land and forest is one of the factors that trigger the fire.

Forests and degraded lands are mainly caused by legal and illegal exploitation of timber and conversion for plantations, rice farming and transmigration. In degraded forests it is more sensitive to fire, because of the ease of ignition and spreading of fire. In addition, people tend to use fire as a means and a cheap and fast way in various activities to support their necessities such as land clearing, plantations, sonor system for rice farming, hunting and fishing. In South Sumatra, the culture of fire use has long been adopted by traditional communities living around forests or shifting cultivators.

\subsection{Empowering Indigneous Farmers by Local Fish Farming}

Local or native fishes on peatlands have important economic value to the communities around the peatlands. Such local fishes can lead to an inflation rate, due to the very high price occurring in certain seasons. It is expected that 
with the touch of cultivation technology it can optimize the potential of local fish to further improve the welfare of fisheries communities in a sustainable manner. It is described the potential associated with biological development strategy by utilizing local fish of peat water that has the ability to adapt directly in these waters. The potential is expected to be able to develop fisheries in order to optimize the waters of peatlands. Main characters of fishes in peatlands are summarized in Table 1. Productivity and income of indigenous farmers in fish farming is presented in Table 2.

\section{a. Gabus Fish Farming}

Gabus fish (Channa striata Bloch) is known as snakehead murrel and is widespread in western Indonesia. Gabus is one of the most important fish groups in everyday life, especially for the people of South Sumatra because it is a very high source of animal protein, especially the source of albumin for people with hypoalbumin (low albumin), and wounds, both wound post surgery or burns.

In South Sumatra, gabus has a high selling price (ranging from Rp 45,000-60,000/kg). Since availability in nature has diminished, as well as the considerable potential of these fish, it is necessary to do cultivation business to meet the needs of consumption and demand for the fish. Gabus fish capable of living in conditions of minimal oxygen, as well as watery conditions are sour. In conditions of ponds or swamps that are almost dry, the fish are able to survive. For the reproduction process by making a nest among the water plants and laying the eggs on the nest and generally a single tail can produce $10,000-15,000$ eggs. Peat water is a potential place for the development of the gabus fish. Seeding techniques and enlargement of these fish can be done naturally, so the development can be done to suppress the extinction of the fish.

Table 1. Main characters of fishes in peatlands

\begin{tabular}{llccc}
\hline Nr & Fish farming & Total eggs (egg/fish) & $\begin{array}{c}\text { Survival rate } \\
\mathbf{( \% )}\end{array}$ & $\begin{array}{c}\text { Water pH } \\
\text { range }\end{array}$ \\
\hline & Local fishes & & & \\
\hline 1 & Gabus & $10.000-15.000$ & $75-90$ & $3.30-8.00$ \\
2 & Tebakang & $25.000-35.000$ & $80-90$ & $4.00-8.00$ \\
3 & Sepat siam & na & $85-90$ & $3.50-9.00$ \\
4 & Betok & $5.000-20.000$ & $80-90$ & $3.00-8.00$ \\
5 & Gurame & na & $80-90$ & $3.00-7.50$ \\
6 & Toman & na & $75-90$ & $3.00-8.50$ \\
\hline B & Introduced Fishes & & & \\
\hline 1 & Patin siam & na & $65-85$ & $4.00-8.50$ \\
2 & Lele dumbo & na & $80-90$ & $3.50-8.00$ \\
3 & Nila & na & $80-90$ & 4.00 \\
\hline Note $\quad$ :na (not available) & & &
\end{tabular}

Table 2. Productivity and income of indigenous farmers in fish farming

\begin{tabular}{llccc}
\hline Nr & \multicolumn{1}{c}{ Fish farming } & $\begin{array}{c}\text { Price } \\
\text { (Rp } \\
\text { thousands/kg) }\end{array}$ & $\begin{array}{c}\text { Pond productivity } \\
\left.\text { (ton/600 } \mathbf{~ m}^{\mathbf{2}} / \mathbf{c y c l e}\right)\end{array}$ & $\begin{array}{c}\text { Income of farmers } \\
\text { (Million/cycle) }\end{array}$ \\
\hline & Local fishes & & & na \\
\hline 1 & Gabus & $45-60$ & na & na \\
2 & Tebakang & $15-25$ & na & na \\
3 & Sepat siam & $15-20$ & na & na \\
4 & Betok & $15-25$ & na & na \\
5 & Gurame & $25-35$ & na & \\
6 & Toman & $30-40$ & na & $8.50-10.60$ \\
\hline B & Introduced Fishes & & & $6.10-7.20$ \\
\hline 1 & Patin siam & $15-18$ & $3.62-4.45$ & na \\
2 & Lele dumbo & $14-17$ & $0.98-1.35$ & \\
3 & Nila & $20-25$ & na & \\
\hline Note & : na (not available) & & &
\end{tabular}

Note : na (not available)

Available online at HABITAT website: http://www.habitat.ub.ac.id

ISSN: 0853-5167 (p); 2338-2007 (e) 


\section{b. Tebakang Fish Farming}

Tebakang or tambakan or biawan fish (Helostoma temminckii Cuvier) is stated as one type of freshwater fish originating from the tropical Asia region. This fish was originally originated from Indonesia and Thailand and has now been introduced to the world. This fish in the world is known as kissing gourami, cultivated for the meat. The tebakang fish in South Sumatra reaches price of $\mathrm{Rp} 25,000,-/ \mathrm{kg}$. In the last few years the tebakang fish became one of the freshwater ornamental fish commodities because of its unique shape and behavior. As a result of its popularity as an ornamental fish, the small tebakang fish about $12-15 \mathrm{~cm}$ was exported to countries such as Japan, Europe, North America and Australia. Outside the country, the $12-15 \mathrm{~cm}$ long sized tebakang fish is sold for US\$2.00$5.00 /$ fish. Tebakang fish can survive in conditions of minimal oxygen and low $\mathrm{pH}$, especially in peat waters. The ability of its reproduction is very high, the tebakang fish are spawned by injected with hormones having the number of eggs (fecundity), which is greater than the natural. Tebakang fish breeding by injecting method can produce 25,000-35,000/100 $\mathrm{g}$ of parent eggs with survival rate of $80-90 \%$. There is an increase in seed production by 1.6-fold when compared with natural spawning. The technology of hatchery and farming of fish has actually been known, but it has not been used, so that the development of the fish becomes less optimal.

\section{c. Sepat Siam Fish Farming}

Sepat siam fish (Trichogaster pectoralis Regan) was originated from Thailand arriving in Indonesia in the year of 1934 through Malaysia. Its natural habitat is mostly cultivated in swamp area. Sepat siam breeds rapidly and is now an important fish, which dominates up to $60 \%$ of swamp fishes. Sepat siam can be cultivated in ponds, ricefields and peat waters with $\mathrm{pH}$ conditions ranging from 4-8. Sepat siam has a respiratory reserve (labyrinth), so the oxygen lack is not a big problem for its. In peat waters, the fish can live and breed well. Sepat siam price in South Sumatra was around Rp 15.000,-/kg and its demand is increasingly high for supply to each region and tends to increase. The market opportunity is quite promising, it cannot be used optimally by the fish farmers. Research to increase fish production and productivity is still continuing to this day. It is expected that the results to be obtained can be applied directly to farmers.

\section{d. Betok Fish Farming}

Betok/papuyu fish (Anabas testudineus Bloch) is known as climbing perch which spread in the Asia region in Asia and are freshwater local fish having high economic value and are favored by the local people especially in South Sumatra, but until now it is still not much cultivated. Betok fish has a price of Rp 25.000,$/ \mathrm{kg}$, however its availability in nature has diminished, thus it needs to be cultivated.

Betok fish have many advantages over other local fish, can live in conditions of oxygenpoor waters, because they have the ability to take oxygen in the water surface, have tolerance to changes in the $\mathrm{pH}$ with a range of $\mathrm{pH} 3-8$ and able to live under poor conditions. The reproductive ability was quite high, the fish was able to spawn 2-3 times/year with the number of eggs (fecundity) generated large enough i.e. 5000-20000 eggs, so the fish has the potential to be cultivated in peat waters. The developed breeding technology is already well developed, namely the method of induced breeding. The percentage of hatchability (HR) of eggs is produced by $80-90 \%$ higher 1.4 to 1.5 times compared with naturally spawning. The degree of survival rate (SR) was around $55-65 \%$ either by spawning or inborn marriage naturally. However, hybridizing between betok fish of Kalimantan and Sumatra can increase the survival rate of 1.21.5 times.

\section{e. Gurame Fish Farming}

Gurame or kalui fish (Osphronemus gouramy Lacepede) known as giant gourami has distributed swamps in Asia. Gouramy breed is by making a nest of twigs in the waters. The fish has extra breathing serving to be able to take oxygen from the air (labyrinth), so it can live and grow in low oxygen conditions. Gurame fish can live and breed in peat waters with $\mathrm{pH}$ values ranging from $3-4$, and the dissolved oxygen content is 3-5 $\mathrm{mg} /$ liter. The price of gurame fish in South Sumatra was around Rp 30,000,-/kg. Information on hatchery techniques or enlargement of gurame fish is still limited and not much owned by farmers. Therefore, the transfer of technology to the fish is necessary for the cultivation of the fish to be developed. Increasing the gurame production is being done by studying genetic populations, selection, and hybridization to accelerate the growth of gurame fish. By looking at the potential and ability of gurame, then 
gurame fish can be developed and cultivated in waters of peatlands.

\section{f. Toman Fish Farming}

Toman fish (Channa micropeltes Cuvier) known as giant snakeheads is widespread in Western part of Indonesia and Southeast Asia. Its soft white flesh makes toman as one of the favorites for grilled fish, crushed or cooked into soup. Toman is also often salted and sold as a salted fish. The price of toman fish in South Sumatra was around $\mathrm{Rp} 30.000,-/ \mathrm{kg}$. The fish availability in nature began to decrease due to the increasing human population, so it is needed to conserve the fish in order to avoid its extinction. This fish has a body shape similar to the gabus fish, but the toman can grow to reach more than one meter long and become the largest species in its family. This fish has an advantage in 'nurturing' her children. Fish mothers are often found to swim around the group of children who are still small. Toman fish is able to live on $\mathrm{pH}$ value of around 3 and dissolved oxygen content less than $3 \mathrm{mg} /$ liter. The young toman fish is beautifully colored and favored as aquarium fish. At this time the fish is still cultivated naturally because the fish mother has the nature in nurturing their children.

\subsection{Empowering Indigneous Farmers by Introduced Fish Farming}

The introduced fishes to the peatland waters should have economic value and can adapt to extreme conditions of peat waters. With the fish farming technology, it can be applied in the peat waters through introduced fish species, it is expected to increase the production and productivity of peat waters.

\section{a. Patin Siam Fish Farming}

Fish of patin siam (Pangasianodon hypophthalmus Sauvage) know as Siamese catfish has high economic value and potential to be developed in peat waters. Patin siam tends to be more resistant to low dissolved oxygen conditions and acidic $\mathrm{pH}$ when compared to other patin relatives and sometimes enters into swamps adjacent to large rivers. Patin siam has a high body resistance to ammonia and other nitrogen discharges.

The high demand for patin siam encourages farmers to compete in cultivating the fish. In addition, technology of seeding and enlargement that has been mastered can increase the production of patin siam in the future. The price of patin siam can reach the range of $\mathrm{Rp}$
$15.000-17.000,-/ \mathrm{kg}$. The peat waters have become one of the potential business opportunities for cultivation of patin siam because patin siam has high adaptability and can live in waters with very low $\mathrm{pH}$ conditions. Patin siam cultivation in peatlands resulted that it was quite satisfactory during the maintenance period of 12 months of patin siam stocked with initial weight of $7 \mathrm{~g}$, which can reach the weight of 900$1000 \mathrm{~g}$ with a survival rate of $66.7 \%$ and FCR 1.4. Thus, the patin siam is potential to be developed in peat waters, and the need for a technology package for the hatching of patin siam can also be done in peat waters. Patin siam cultivation is done quite successfully with the productivity of pond $600 \mathrm{~m}^{2} /$ cycle and in 8 months, it could be harvested around 3.62-445 tons with income of farmers ranging from $\mathrm{Rp}$ 8.50-10.60 million/cycle.

\section{b. Lele Dumbo Fish Farming}

Lele dumbo fish (Clarias gariepienus Burchell) known as dumbo catfish is able to live and grow in conditions of waters that are less oxygen and low $\mathrm{pH}$. The fish is expected to be preserved in the peatland waters because it has additional breathing tools, which causes the fish is able to live well in low-oxygen waters (2-3 $\mathrm{mg} /$ liter). The fish is also able to live in aquatic conditions having $\mathrm{pH}$ values of 3-4 and high ammonia levels $(0.50-1.00 \mathrm{mg} /$ liter $)$, so the fish is widely developed in peat waters. Lele dumbo farming in peat waters has been commonly done by many local people with limitations of information and technology. In two months of lele dumbo farming is able to grow to reach the size of 100-150 g/fish with the initial size of 5-7 $\mathrm{cm}$. The survival level is high at $70-80 \%$ level with FCR 1.5. The price of lele fish in South Sumatra was around Rp 14.000-17.000, $/ \mathrm{kg}$ meaning that lele dumbo farming in peat waters is very promising, especially in peat waters.

\section{c. Nila Fish Farming}

Nila fish (Oreochromis niloticus Linnaeus) known as tilapia belongs to superior product introduced by government. The fish has the potential to be developed because it can survive against bad environments and different maintenance systems. Tilapia is one of the introduced fish that has been successfully cultivated in peat waters. The result that has been achieved is the acquisition of tilapia fish candidate that can be developed in peat waters. Tilapia candidate is the BEST tilapia imported from the Center for Research and Development 
of Freshwater Aquaculture (BPPBAT) Bogor. The fish has a higher growth advantage of 2.6 times with a rate of $160 \%$ better than the local tilapia developed in the area.

The use of tilapia from breeding results will increase production by 2.60 times higher, so that the income of the farmers of tilapia will increase also. The price of the tilapia is not less competitive than other local fish, which ranges between $\mathrm{Rp} 20.000-25.000,-/ \mathrm{kg}$. So the opportunities in the development of tilapia especially nila breeding results in peat water has a very big prospect. Seeing the potential and opportunities, then for the development of tilapia in the waters of the peat is highly recommended. Meanwhile, the productivity of tilapia cultivation with an area of $600 \mathrm{~m}^{2} /$ cycle of 5 months was around 0.98-1.35 tons and income of farmers was about Rp 6.10-7.20 million/cycle.

\subsection{Empowering Indigneous Farmers with Technology Approach}

Peatlands can be illustrated like the human body, meaning that biomass and soil nutrients that have been harvested or lost must be replaced, thus soil nutrient balance can be properly maintained in a balanced and stable state. Appropriate drainage system action, balanced aeration and balanced soil nutrition can keep peatlands and commodities cultivated healthy and environmentally sound. If peatlands are healthy and environmentally friendly, thus peatlands will be able to automatically support fish and food crop farming and maintain existence of peatlands as whole. Because tropical temperature is higher than temperate temperature, therefore tropical peatlands will release more carbon dioxide than temperate peat, thus it is required to replace all the lost organic material by restoring the residues of the agricultural harvest to the peatlands to maintain a peatland biomass balance.

The most prohibited action on peatland is mentioned as land clearing by burning because peatland burning will globally destroy the peatland system as a whole, and destroy peatland functions as a supporter of human life. Peatlands are naturally very diverse in many aspects, such as groundwater depth, maturity level, vegetation presence and vegetation type and others. The most effective and efficient way to distinguish the diverse peat types is peat mapping, but mapping of peatlands is expensive and often not done before the peatlands would be used for agricultural activities in a broad sense.

It can be concluded that peatlands can be utilized for agricultural activities in the broad sense as long as the cultivated commodities have to be in accordance with the suitability of peatland, for example the utilization of peatlands for fisheries, food agriculture, plantations and others. The basic concept of peatland utilization should be based on the conservation of peatland resources, which should be initiated from the concept of "maintaining water and soil nutrition" (Table 4). Technology for empowering farmers with fish farming can be focused on drainage and irrigation systems to maintain groundwater levels; and application of soil ameliorant (e.g. dolomite for fish ponds, lime, manure, urea and NPK fertilizer).

Table 4. Technology for empowering indigneous farmers with fish farming

\begin{tabular}{llll}
\hline Nr & Technology & \multicolumn{1}{c}{ Description } & \multicolumn{1}{c}{ Threshold values } \\
\hline 1 & Drainage/ & Maintaining surface & Fish farming $(40-60 \mathrm{~cm}) ;$ plantation $(50-80 \mathrm{~cm}) ;$ and \\
& irrigation & ground water & Food farming $(30-50 \mathrm{~cm})$ \\
2 & Soil & Maintaining soil pH & Dolomite for fish ponds $\left(100 \mathrm{~g} / \mathrm{m}^{2}\right) ;$ lime $\left(1 \mathrm{~kg} / \mathrm{m}^{2}\right) ;$ \\
& ameliorant & of $4.50-6.50$ & manure $\left(300 \mathrm{~g} / \mathrm{m}^{2}\right) ;$ Urea $\left(20 \mathrm{~g} / \mathrm{m}^{2}\right) ;$ and NPK $\left(10 \mathrm{~g} / \mathrm{m}^{2}\right)$ \\
\hline
\end{tabular}

\section{a. Drainage and Irrigation}

The main purpose of drainage and irrigation is to maintain the peatland soil water in stable levels during the year, so that water management in the fish pond can be properly managed and controlled. It is continued with making of ponds and conducted cleaning ponds from the terraces to the inside of the ponds. In general, in the pond processing it is firstly done by drying ponds and soil processing, but the existing pond is done in two ways. Firstly, water is taken out by the pump and secondly without pump. It is relatively difficult to dry because pond water seeps continuously from outside the ponds.

\section{b. Liming}

Water acidity becomes a main constraint for fish farming. Cultivation of freshwater fish (especially patin and nila) in peatlands is feasible and potential to be developed. The freshwater 
fish cultivation is still dominated by pond water use tidal system relies on up and down river water. It is often constrained the arrival of acid water with low $\mathrm{pH}$ value under 3 , which is poisonous causing the death of fish cultivation in the pond.

Liming using dolomite is able to eradicate pests or diseases, improve soil structure and raise $\mathrm{pH}$ at doses less than $300 \mathrm{~g} / \mathrm{m}^{2}$. Limiting the pond using dolomite lime with dolomite dose for fish ponds $\left(100 \mathrm{~g} / \mathrm{m}^{2}\right)$ when the pond is dry with the purpose of eradicating pests/diseases, improving soil structure and raising the $\mathrm{pH}$. Lime (dose $1 \mathrm{~kg} / \mathrm{m}^{2}$ ) is spread evenly on the surface of pond bottom and pond wall. The pond is silenced without treatment until maximum 15 days. After liming and fertilization $\mathrm{pH}$ control continues to be done every 2 (two) days. If the $\mathrm{pH}$ is still $<5$, then reliming using dolomite $\left(100 \mathrm{~g} / \mathrm{m}^{2}\right)$, if the $\mathrm{pH}$ of water has reached 5-6, it can be done stocking of fish seed.

\section{c. Fertilization}

Fertilization is carried out around 3-5 days after liming to allow time for the stocked lime to react with soil and pond water, and then the pond is allowed to stand at least 15 days to wait for the water $\mathrm{pH}$ reaches 5 . If the water $\mathrm{pH}$ has reached 5 , then the fish seed can be stocked and continued with fish maintenance. Manure is given at a dose of $300 \mathrm{~g} / \mathrm{m}^{2}$ and spread to the pond or burrow the manure packed in plastic sacks into the pond for the purpose of adding nutrients, so the plankton can grow and is expected to increase the water $\mathrm{pH}$. A day after fertilizer application of manure, Urea and NPK fertilizers are added with Urea dosage $\left(20 \mathrm{~g} / \mathrm{m}^{2}\right)$; and NPK $\left(10 \mathrm{~g} / \mathrm{m}^{2}\right)$ which is also spread evenly on the water surface in order to increase the pond fertility.

\section{Conclusions}

Based on the results and discussion of this research, it can be drawn some conclusions as follows:

1) The main problem of peatlands is forest and land fire occurring every year especially in dry season and has caused a lot of losses for all parties.

2) The prospect of empowering indigenous farmers by fish farming in peatlands is very high, which is divided into local fish farming (e.g. fishes of gabus, tebakang, sepat siam, betok, gurame, and toman), and introduced fish farming (i.e. fishes of patin siam, lele dumbo and nila).

3) Technology for empowering indigenous farmers with fish farming can be focused on drainage and irrigation systems to maintain groundwater levels; applying soil ameliorant (e.g. dolomite for fish ponds, lime, manure, urea and NPK fertilizer).

It is suggested that the moratorium on government regulations of peatland restoration should be taken as a bright spot to ensure the sustainability of peatlands. Thus, it is necessary to educate indigenous farmers and private large companies with humanist approaches to be directly involved to conserve and to maintain the sustainability of peatlands.

\section{Acknowledgments}

The research of this article was funded by DIPA of Public Service Agency of Universitas Sriwijaya 2020. SP DIPA-023.17.2.677515 12020 , revision IV, On July $02^{\text {nd }} 2020$. In accordance with the Rector's Decree Number: 0009/UN9/SK.LP2M.PT/2020 on September $28^{\text {th }} 2020$. On this good occasion, we would like to thank to all staff of the Faculty of Agriculture, Sriwijaya University, undergraduate and post graduate students who have greatly assisted in the research both in the field and in the laboratory. Thank you also to all parties who cannot be mentioned one by one who has contributed directly to the implementation of research in the field. Especially to local workers who have been enthusiastic to help, for this we want to say many thanks.

\section{References}

Adriani, D. and E. Wildayana. 2015. Integrasi Pertumbuhan Ekonomi dan Penciptaan Kesempatan Kerja Sektor Pertanian di Indonesia. Jurnal Sosiohumaniora Unpad. Vol 18(3); 204-212, Nov 2015.

Armanto, M.E., M.A. Adzemi, E. Wildayana and M.S. Imanudin. 2013. Land Evaluation for Paddy Cultivation in the Reclaimed Tidal Lowland in Delta Saleh, South Sumatra, Indonesia. Journal of Sustainability Science and Management. Vol 8(1):32-42. June 2013. 
BPS South Sumatra. 2016. Sumatera Selatan dalam Angka 2015. BPS Sumatera Selatan. Palembang.

Dikici, H. and C.H. Yilmaz. 2006. Peat Fire Effects on Some Properties of an Artificially Drained Peatland. Journal of Environmental Quality. Vol 35(3); 866870.

Firmansyah, M.E. Armanto, R.H. Susanto, J. Arliansyah and M. Yazid. 2016. Community Perception of Rural Road Network in Tanjung Lago District of Banyuasin South Sumatra. Asian Jr. of Microbiol. Biotech. Env. Sc. Vol. 18(1); 133-138

Hadden, R., R. Guillermo and C. Belcher. 2013. Study of the Competing Chemical Reactions in the Initiation and Spread of Smouldering Combustion in Peat. Proceedings of the Combustion Institute. Vol 34(2); 2547-2553.

Hooijer, A., S. Page, J. Jauhiainen, W.A. Lee, X.X. Lu, A. Idris, and G. Anshari. 2012. Subsidence and Carbon Loss in Drained Tropical Peatlands. Biogeosciences. Vol 9(3); 1053-1071.

IPCC. 2014. 2013 Supplement to the 2006 IPCC Guidelines for National Greenhouse Gas Inventories: Wetlands, Hiraishi, T., Krug, T., Tanabe, K., Srivastava, N., Baasansuren, J., Fukuda, M. and Troxler, T.G. (eds). Published: IPCC, Switzerland.

Ismawi, S.M., S. Gandaseca and O.H. Ahmed. 2012. Effects of Deforestation on Soil Major Macro-Nutrient and other Selected Chemical Properties of Secondary Tropical Peat Swamp Forest. Int. J. Physic. Sci. Vol. 7(14); 2225-2228.

Könönen, M. J. Jauhiainen, R. Laiho, K. Kusin and H. Vasander. 2015. Physical and Chemical Properties of Tropical Peat under Stabilized Land Uses. Mires and Peat, Vol 16(8); 1-13.

Lampela, M., J. Jauhiainen and H. Vasander. 2014. Surface Peat Structure and Chemistry in a Tropical Peat Swamp Forest. Plant and Soil. Vol 382(1-2); 329 347. September 2014

Oktavia, Z., Darwanto, D.H., Hartono S. 2014. Sektor Pertanian Unggulan di Sumatera
Selatan. Jurnal Agraris. Vol 1(2); 61-69. Ekonomi Pertanian, Universitas Gadjah Mada, Yogyakarta.

Sarno, R.A. Suwignyo, Z. Dahlan, Munandar, M.R. Ridho, N. Aminasih, Harmida, M.E. Armanto and E. Wildayana. 2017. The phenology of Sonneratia alba J. Smith in Berbak and Sembilang National Park, South Sumatra, Indonesia. Biodiversitas. Vol 18(3); 909-915, July 2017. DOI: 10.13057/biodiv/d180307.

Wildayana, E., A.S. Busri and M.E. Armanto. 2016. Value Changes of Lebak Swamp Land over Time in Jakabaring South Sumatra. Journal of Wetlands Environmental Managements. Vol 4(1); 46-54. April 2016. 